\title{
Forecasting Regional Indicators Based on the Quarterly Projection Model
}

\author{
Alyona Nelyubina, Bank of Russia; Lomonosov Moscow State University \\ nelyubinaas1558@gmail.com
}

The paper presents a semi-structural model of a regional economy based on the standard version of the neo-Keynesian model in gaps. The main feature of this tool is its ability to predict regional indicators and model the regional heterogeneity of the national economy. In our model, Russia is divided into two macro-regions: the Central Federal District and the rest of Russia in aggregate. These regions are modelled separately but are interrelated. The benefit of this approach is that it allows us to analyse how shocks in one region are passed along to others, how the regions react to general shocks and what the appropriate monetary policy response should be. The model represents a simple and convenient tool for building macroeconomically consistent forecasts and generating recommendations in the area of monetary policy based on regional specifics.

Keywords: semi-structural model, forecast, monetary policy, Russian regions, federal districts

JEL Codes: E52, E31, E32
Citation: Nelyubina, A. (2021). Forecasting Regional Indicators Based on the Quarterly Projection Model. Russian Journal of Money and Finance, 80(2), pp. 50-75.

doi: $10.31477 /$ rjmf.202102.50

\section{Introduction}

At the end of 2014, the Bank of Russia adopted an inflation-targeting regime aimed primarily at maintaining the rate of price growth near the inflation target. In this regard, it is critical to understand what the forecast trajectory of inflation will be in the medium term, and what the monetary authorities should do to achieve the target.

The Bank of Russia focuses on the inflation path for Russia as a whole. However, the inflation rate for Russia in general is an aggregated indicator based on the weighted values of inflation in the regions. The Russian economy is fairly heterogeneous in terms of regions, with significant regional differentiation in the inflation rates. To maintain an effective monetary policy, it is necessary to consider all information available at the time of decision-making and to envision the future trajectories of price indicators, including regional ones.

The paper presents a regional quarterly projection model (QPM) as a tool for mid-term forecasting of regional economic development. This is a standard 
semi-structural model (Berg et al., 2006a, 2006b). However, it takes regional specifics into account. The model includes three regions: the Central Federal District (CFD), the rest of Russia, and the rest of the world. This regional division makes it possible to analyse the implications of both local and general shocks.

The paper is structured as follows. The literature review (Section 2) presents the logic of the QPM, describes the experience of forecasting regional indicators using semi-structural models, and highlights the importance of considering regional specifics. Section 3 describes the regional model and key behavioural equations. Sections 4 and 5 present the results of modelling. Section 6 concludes.

\section{Literature review}

Before describing the model, let us explain why it is important to understand the expected trajectories of regional indicators in order to implement a monetary policy. The difference in the rates of price growth can become a challenge in conducting monetary policy. Sinelnikov-Murylev et al. (2020) identify a number of problems that can result from the regional differentiation of inflation. First, despite a single nominal rate set by the central bank and the same risk premium in the regions, real regional interest rates will differ. In this case, monetary policy may have different impact on the different regions. In regions with relatively high inflation, the real interest rates are lower; therefore, a rate hike by the regulator may be insufficient to raise the real rate in the region. In extreme cases, relatively low real rates can lead to stronger investment and consumer demand in these regions, which, in turn, will result in a further increase of aggregate demand and additional inflationary pressure. Second, if the overall price level decreases in one region while increasing in others, such region is at risk of falling into a deflationary spiral.

An important question regarding inflationary differentiation in the regions is whether the differences are temporary or persistent. If the differences are temporary, the average inflation levels in different regions will ultimately converge; if the differences are persistent, there will be no convergence, which may pose a challenge in implementing monetary policy. In their papers, de Haan (2010) and Beck et al. (2009) identify the factors affecting inflationary differentiation and discuss the extent of their persistence. Factors affecting differences in the rates of price growth may be:

1) Price level convergence. It is assumed that prices in the regions are different, but they converge to each other at various rates, which may temporarily lead to differences in the inflation level. When, for example, the price level in one region is lower than in the others, it is logical to assume that, if the price levels in the regions tend to converge, then in that region prices will increase at a higher rate until their level reaches the national average.

2) Differences in business cycles. It is assumed that a positive output gap (when the actual output is higher than the potential equilibrium value) 
creates inflationary pressure in a region, while a negative one creates disinflationary pressure.

3) Specific supply and demand shocks and asymmetric responses to general shocks. This factor is related to regional characteristics. Regions may have their fiscal policy, sectoral specialisation, degree of economic openness, etc. Therefore, the regions can be affected by specific unexpected changes (such as a fiscal policy shock) or can respond differently to a general monetary shock due to the specifics of the transmission mechanism.

4) Peculiarities of labour and other production factors' markets. The growth rates of wages may differ across regions given the heterogeneity of their labour markets. The differences in wage changes lead to differences in production costs and, therefore, different rates of price growth.

5) Rigidity of prices and wages. This factor is related to the level of competition in the regions. The higher the competition, the harder it is for firms to keep prices unchanged (lower rigidity), and the more flexible is the response to changes in monetary policy.

The first three factors do not pose a substantial challenge for monetary policy, since they assume that the differences in inflation are temporary, and eventually the rates of price growth will converge. The next two factors though are institutional and can have a persistent impact on inflationary differentiation.

There are a few theoretical and empirical studies on the factors that explain the differences in price levels and inflation in the Russian regions. For example, Perevyshin et al. (2017) believe that one of the key reasons for the differences in the price level across the Russian regions during 2000-2015 is the BalassaSamuelson effect, the costs of regional trade (the distance of the region from other regions of Russia), and the monopolisation level in retail trade. SinelnikovMurylev et al. (2020) use panel data and find that Russian regions have different inflation because of factors specific to each region. These factors include (a) the output gap; (b) inflation expectations; (c) the exchange rate pass-through effect; and $(\mathrm{d})$ regional price convergence. The authors find that the convergence of regional prices to the national level is the most important factor. Zhemkov (2019) investigates the reasons for the deviation of regional inflation from the national level and estimates the 'structural' inflation for each macro-region to find that inflation in the regions can consistently deviate from the target level. These deviations can be explained by such factors as 'the Balassa - Samuelson effect, the dynamics of effective exchange rates, real money income, and inventories'.

Deryugina et al. (2019) assess the impact of regional and sectoral factors on national inflation. After estimating the dynamic hierarchical factor model, the authors find that regional characteristics have no significant impact on inflation in Russia as a whole, while sector-specific characteristics have such impact. Novak and Shulgin (2020) note that the findings by Deryugina et al. (2019) 'do not reduce the significance of the regional aspect in monetary policy, since both 
the sectoral aspect (given the low level of diversification in the regional production structure) and a certain share of idiosyncratic shocks must be considered as regional problems'.

Thus, the studies available at this point are insufficient for concluding whether the factors that affect regional differentiation are persistent. It is also worth noting that understanding the expected inflation path and other indicators under different regional scenarios is important for an effective monetary policy. First, the Russian inflation indicator is an aggregate value of the inflation rates in the regions. Employees of regional branches of the Bank of Russia are better informed about the situation in their region, so they may have information that is not yet reflected in the statistics (Novak and Shulgin, 2020). In other words, availability of regional information enables one to envision a more accurate trajectory and scenarios. Second, this may be necessary when implementing a better communication policy (Zhemkov, 2019), which is an important tool in the process of 'expectations anchoring. In addition, the Bank of Russia (2020) points out the importance of expanding regional communication and wider coverage of regional trends through a range of regular publications on the economic situation in the regions provided by the regional branches of the Bank of Russia. Since December 2020, the Bank of Russia has been publishing regular reports by its Main Branches on the trends in economic development in the Russian regions. ${ }^{1}$

At this time, there is a number of models that address the issue of forecasting indicators for a particular economy within a common currency area. First of all, these include the structural models designed by the national banks of the euro area for their countries. They were created to account for the structural specifics of a particular country. Such models generally divide the euro area into two subregions: the country in question and the rest of the euro area in aggregate. These include, for example, the models of Belgium (Jeanfils and Burggraeve, 2008), Spain (Burriel et al., 2010), Germany (Gadatsch et al., 2016), and many others.

There are not many academic papers describing semi-structural models that forecast indicators for a particular economy within a common currency area. Jakab et al. (2015) present a global projection model that describes a multi-country economy (about $85 \%$ of global GDP). It includes six regions (the United States, the euro area, Japan, emerging markets in Asia, five inflation-targeting Latin American countries, and remaining countries grouped together) interconnected through realeconomy and financial relationships. For each region (other than the euro area), the authors generate the aggregate demand equation, the Phillips curve, the uncovered interest rate parity (UIP) equation, and a monetary policy rule. The economies in the model are linked in such a way that economic activity in one region is affected by the levels of economic activity in other regions, exchange rates and variables that describe the tightening of bank lending in the United

${ }^{1}$ See https://www.cbr.ru/eng/press/event/?id=8399 
States, the euro area, and Japan. The model includes both national demand shocks and general or global shocks. In turn, the euro area is divided into five more regions: Germany, France, Italy, Spain (which together account for about 15\% of global GDP), and the rest of the euro area in aggregate. The separate aggregate demand and Philips curve equations are used for each region of the euro area, while UIP and monetary policy equations are common for the entire euro area.

Pienkowski (2019) presents a semi-structural model for Portugal, which is a modification of the standard model (Berg et al., 2006a) but includes three regions: Portugal, the rest of the euro area, and the rest of the world. For each of these regions, the authors also define the output gap and inflation equations, while the UIP equations and the monetary policy rule are common. This approach makes it possible to see how shocks in one country are transmitted to others, and what the monetary policy response should be in a situation when countries are united in a common currency area.

There is no published literature describing regional semi-structural models for Russia. The first papers on designing a QPM for Russia as a whole include Borodin et al. (2008) and Borodin (2014), which present a model developed by the Bank of Russia based on the specifics of the Russian economy. At this time, the regulator uses this QPM supplemented on the basis of accumulated experience in modelling and forecasting (Orlov, 2021). Also, Demidenko et al. (2016) present a multi-country QPM, in which Russia is connected to other countries through trade flows.

\section{Model description}

The QPMs are an element of the model apparatus used for theoretical research and practical applications of modern central banks. The models are designed for medium-term forecasting and decision-making support in monetary policy. QPM belongs to the class of New Keynesian models that include the principles of dynamic general equilibrium models, and gives adequate consideration to expectations, on the one hand, and to the IS/LM model, which takes into account the effects of monetary policy, on the other hand. For more details on QPM logic, see, for example, Berg et al. (2006a, 2006b), Beneš et al. (2003), Mogilat (2017).

Our model is based on the standard version described by Berg et al. (2006a, $2006 \mathrm{~b}$ ) but takes into account the specifics of the regional economy. The main modification of the regional QPM is that Russia is divided into two regions, such as the CFD and the rest of Russia (RoR) in aggregate, which are modelled separately but are closely interrelated. It is worth noting that the CFD is just an example (the convenience of this example is that the subjects of the federal district match the subjects of the Bank of Russia Main Branch for the CFD), but the model can also be used to forecast the situation in other regions (for instance, in a similar way, it is possible to take another federal district, a subject of the Russian Federation, or 
other Main Branch of the Bank of Russia). A similar approach is used, for example, in the paper of Albonico et al. (2017), where the authors designed a multi-country dynamic stochastic general-equilibrium (DSGE) model with the euro area divided into two subregions (the country in question and the rest of the euro area) that are connected by trade and financial flows and also have a single monetary policy.

The model is based on a system of behavioural equations describing the relationship between inflation, business activity, exchange rate dynamics, interest rates, terms of trade, and external sector variables. The dynamics of inflation components are formulated separately for the CFD and separately for the rest of Russia. Russian inflation is their weighted average. Similarly, separate output gap equations are modelled for the CFD and the rest of Russia. The dynamics of Russian demand is also represented by weighted averages. The UIP equation and the monetary policy rule are used for Russia as a whole.

The equations are parameterised by calibration with elements of Bayesian assessment. Calibration is selected as the main method of estimation because it enables estimates that come close to true ones even on short data series and when structural shifts exist, which is typical of Russia. The coefficients are based on the recommendations and ranges set by international practice (for example, Berg et al., 2006a, 2006b). In addition, we focus on the QPM for Russia as a whole (Demidenko et al., 2016). To describe the regional differences, we used expert judgment and Bayesian assessment.

During calibration, we considered the following key characteristics:

- The high degree of inertia in economic processes associated with the peculiarities of the Russian economy's structure;

- The high degree of inertia in inflation expectations due to the fact that the Bank of Russia adopted an inflation targeting regime at the end of 2014 and is currently in the process of anchoring inflation expectations;

- The different degree of impact made by the exchange rate on inflation components due to the different scale of the exchange rate pass-through effect on inflation.

In addition, the elasticity coefficients in the regional equations take the heterogeneity of the regions into account. At the first stage of calibration, the same equation coefficients were set for both regions (based on global or Russian practice). Next, some parameters are adjusted in accordance with additional studies or expert judgments. For example, our calculations show that the share of imported goods in the CFD is higher than in other Russian regions; respectively, in the CFD, the coefficient of inflation elasticity to the exchange rate should be higher than in Russia as a whole. Also, we assumed that the oil price elasticity of regional output in the CFD is lower than in the rest of Russia since oil companies are located in other regions, and only their head offices are located in the CFD. Similarly, we had hypotheses about other coefficients. Next, we made the diagnostics of the model with modified coefficients by analysing the impulse 
response functions and in-sample forecasts, and analysing the decompositions of variables using the Kalman filter in order to determine the quality of the calibration.

The QPM is built using the variables as gaps. In this case, the gap means the deviation of the actual indicator from the trend value. In turn, the trend is the long-term expected value determined by fundamental factors. Trends in the QPM are usually modelled by autoregressive processes converging to their stationary states. ${ }^{2}$ This simplification is made mostly because the main purpose of semistructural models is forecasting. In our model, trends are identified using a multidimensional Kalman filter. The logic for calibrating the trend values is that they change smoothly and slowly; therefore, their equations contain a significant degree of inertia and low standard deviations of shocks.

The key idea of the regional model is the transmission mechanisms at the regional level. Let's assume that the central bank cuts its key rate. A change in the key rate leads to a change in the market rates in the CFD. The reduction of market rates in the region has a stimulating impact on demand in the debt market. For firms, credit resources become more accessible and attractive. Increased availability of credit means an inflow of additional funds to finance demand in the CFD. In addition, demand in the CFD is affected by a regional factor such as regional budget policy, as well as external factors, such as foreign demand, terms of trade, and the exchange rate. Special attention should be paid to the exchange rate channel, since it plays an important role in the transmission mechanism. The changes in the exchange rate affect inflation, both directly (through the prices of imported goods and services) and indirectly (through the aggregate demand and output). The indirect impact of the exchange rate on inflation through aggregate demand occurs as follows: a reduction in the key rate weakens the national currency, which, in turn, increases the prices of imported goods. As a result, local products become relatively more attractive to consumers, and the products of the national economy become more competitive abroad. This increases net exports and, subsequently, leads to higher aggregate demand and output.

Similar processes are also taking place in the rest of Russia. Since the regions are closely interrelated, the demand of the CFD is affected by economic activity in the rest of Russia. Next, demand dynamics in the CFD becomes the primary factor for the formation of prices in the market of goods and services and, accordingly, inflation in the region.

It should be noted, that the external sector is modelled separately similar to Demidenko et al. (2016). Trade links affect supply and demand in each of the economies and are built into the model using 'effective' variables, such as effective foreign demand and the real effective exchange rate.

The key macroeconomic relationships are reflected in the following equations.

\footnotetext{
2 The equations of trend components used in the key behavioural equations are provided in the Appendix.
} 


\section{Aggregate demand curve in the region}

$$
\begin{aligned}
& \hat{y}_{t}^{c f d}=\alpha_{1}^{c f d} \times E \hat{y}_{t+1}^{c f d}+\alpha_{2}^{c f d} \times \hat{y}_{t-1}^{c f d}-\alpha_{3}^{c f d} \times r r_{-} \widehat{\operatorname{mar}} k e t_{t-1}^{c f d} \\
&+\alpha_{4}^{c f d} \times \hat{z}_{t-1}+\alpha_{5}^{c f d} \times \widehat{r p o l} l_{t}+\alpha_{6}^{c f d} \times \hat{y}_{t-1}^{f} \\
&+\alpha_{7}^{c f d} \times \hat{y}_{t-1}^{r o r}+\alpha_{8}^{c f d} \times \widehat{d e f_{t}^{c f d}}+\varepsilon_{t}^{y_{-} c f d},
\end{aligned}
$$

where $\hat{y}_{t}^{c f d}$ is the output gap in the CFD, $E \hat{y}_{t+1}^{c f d}$ is the expected value of the output gap in the CFD for one quarter ahead, $r r_{-} \widehat{\text { market }} t_{t}^{c f d}$ is the market rate gap in the CFD, $\hat{z}_{t}$ is the real effective exchange rate gap, $\widehat{r p o l}_{t}$ is the real oil price gap, $\hat{y}_{t}^{f}$ is the effective external demand gap, $\hat{y}_{t}^{\text {ror }}$ is the output gap of the rest of Russia, $d e f_{t}^{c f d}$ is the budget deficit gap in the CFD, and $\varepsilon_{t}^{y_{c}} c f d$ is the demand shock in the CFD.

Equation (1) is a standard aggregate demand curve with some modifications. The common economic theory assumes that a higher interest rate reduces aggregate demand because it makes credit more expensive. This assumption arises from the problem of intertemporal consumer choice, the solution of which involves selecting an optimal consumption level at the current period and in the future. The higher the interest rate, the greater the cost of credit that a consumer can use to finance current consumption. This is one of the main channels for the influence of monetary policy on the economy in the inflation targeting model. The equation also takes into account the rational expectations of consumers seeking to smooth their consumption over time (forward-looking lag of the output gap) and the inertia of economic processes (backward-looking lag of the output gap). As a rule, the sum of coefficients for forwardlooking $\left(\alpha_{1}^{c f d}\right)$ and backward-looking $\left(\alpha_{2}^{c f d}\right)$ lags lies in the range between 0.5 and 0.9 , which reflects the comparative scale of the region's economy. ${ }^{3}$ Since the inertia in the transmission mechanism of monetary policy is characteristic for most economies, it is assumed that the sum of the coefficients $\alpha_{3}^{c f d}$ and $\alpha_{4}^{c f d}$ must be less than the value of the coefficient $\alpha_{2}^{c f d}$ and should be in the range of 0.1 to 0.2 .

To represent the external sector effect on domestic demand, the equation includes effective external demand approximating the level of business activity abroad; the real price of oil as the dependence of demand on changes in the price of oil is characteristic of Russia; and the real exchange rate reflecting the relative prices for domestic goods. The extent of the economy's openness is reflected in the parameter $\alpha_{4}^{c f d}$, and for developing economies it should be less than $\alpha_{3}^{c f d}$ ( 0.05 vs 0.1 , accordingly). The parameters $\alpha_{5}^{c f d}$ and $\alpha_{6}^{c f d}$ are calibrated at levels that allow the impact of real oil price dynamics (with a weight of 0.02 ) and effective external demand (with weight of 0.05 ) on the output gap observed in previous periods to be taken into account.

Regional peculiarities include the region's fiscal policy, which is reflected in the model using a cyclically adjusted budget deficit. ${ }^{4}$ The coefficient for this variable

\footnotetext{
${ }^{3}$ A detailed description of the coefficients is provided in Berg et al. (2006a, 2006b) and, for the Russian economy, in Demidenko et al. (2016).

${ }^{4}$ See more about the budget deficit equation in the Appendix.
} 
$\alpha_{8}^{c f d}$ has a value that is typical of the region (0.15). In addition, since the Russian regions are interlinked by trade, migration, and tourism flows, business activity in one region affects activity in another, which is accounted for in the CFD output gap equation by including the output gap of the rest of Russia. We assume that the demand of the rest of Russia has a greater impact on the CFD economy compared to foreign demand, which is reflected in the greater value of the coefficient $\alpha_{7}^{c f d}$ (at 0.25).

The dynamics of demand in the rest of Russia is modelled in a similar way. The output gap for Russia as a whole is the weighted average of output gaps in the regions:

$$
\hat{y}_{t}^{r u}=y_{-} c f d_{-} w e i g h t \times \hat{y}_{t}^{c f d}+\left(1-y_{-} c f d_{-} w e i g h t\right) \times \hat{y}_{t}^{r o r},
$$

where $y_{-} c f d \_$weight is the weight of the CFD GRP in Russia GDP.

Separate Phillips curves are formulated for food, non-food products, and services other than housing and utility services. Separate curves for the inflation components make it possible to model the different scale of the exchange rate passthrough effect on prices and the different volatility of components.

\section{Phillips curve for food products}

$$
\begin{array}{r}
\pi_{t}^{p_{-} c f d}=\beta_{1}^{p_{-} c f d} \times E \pi_{t+1}^{p_{-} c f d}+\left(1-\beta_{1}^{p_{-} c f d}\right) \times \pi_{t-1}^{p_{-} c f d}+\beta_{2}^{p_{-} c f d} \times \hat{z}_{t} \\
+\beta_{3}^{p_{-} c f d} \times \hat{y}_{t}^{c f d}-\beta_{4}^{p_{-} c f d} \times \widehat{\operatorname{lrp}}_{t}^{p_{-} c f d}+\varepsilon_{t}^{p_{-} c f d},
\end{array}
$$

where $\pi_{t}^{p_{-} c f d}$ is the food inflation, $E \pi_{t+1}^{p_{-} c f d}$ is the expected food inflation for one quarter ahead, $\hat{z}_{t}$ is the real exchange rate gap, $\hat{y}_{t}^{c f d}$ is the CFD output gap, $\widehat{\operatorname{rrp}}_{t}^{p_{-} c f d}$ is the relative price gap, and $\varepsilon_{t}^{p_{-} c f d}$ is the food inflation shock.

Phillips curve for non-food products

$$
\begin{aligned}
& \pi_{t}^{n p_{-} c f d}=\beta_{1}^{n p_{-} c f d} \times E \pi_{t+1}^{n p_{-} c f d}+\left(1-\beta_{1}^{n p_{-} c f d}\right) \times \pi_{t-1}^{n p_{-} c f d} \\
& +\beta_{2}^{n p_{-} c f d} \times \hat{z}_{t}+\beta_{3}^{n p_{-} c f d} \times \hat{y}_{t}^{c f d}-\beta_{4}^{n p_{-} c f d} \times \widehat{\operatorname{lrp}}_{t}^{n p_{-} c f d}+\varepsilon_{t}^{n p_{-} c f d}
\end{aligned}
$$

where $\pi_{t}^{n p_{-} c f d}$ is the non-food inflation, $E \pi_{t+1}^{n p_{-} c f d}$ is the expected non-food inflation for one quarter ahead, $\hat{z}_{t}$ is the real exchange rate gap, $\hat{y}_{t}^{c f d}$ is the CFD output gap, $\widehat{\operatorname{rrp}}_{t}^{n p_{-} c f d}$ is the relative price gap, and $\varepsilon_{t}^{n p_{-} c f d}$ is the food inflation shock.

Phillips curve for services other than housing and utility services

$$
\begin{array}{r}
\pi_{t}^{s w u_{-} c f d}=\beta_{1}^{s w u_{-} c f d} \times E \pi_{t+1}^{s w u_{-} c f d}+\left(1-\beta_{1}^{s w u_{-} c f d}\right) \times \pi_{t-1}^{s w u_{-} c f d} \\
+\beta_{2}^{s w u_{-} c f d} \times \hat{z}_{t}+\beta_{3}^{s w u_{-} c f d} \times \hat{y}_{t}^{c f d} \\
-\beta_{4}^{s w u_{-} c f d} \times \widehat{\operatorname{lrp}}_{t}^{s w u_{-} c f d}+\varepsilon_{t}^{s w u_{-} c f d},
\end{array}
$$

where $\pi_{t}^{\text {swu } c f d}$ is the inflation of services other than housing and utility services, $E \pi_{t+1}^{s w u_{-} c f d}$ is the expected inflation of services other than housing and utility services for one quarter ahead, $\hat{z}_{t}$ is the real exchange rate gap, $\hat{y}_{t}^{c f d}$ is the CFD 
output gap, $\widehat{\operatorname{lrp}}_{t}^{s w u_{-} c f d}$ is the relative price gap, and $\varepsilon_{t}^{s w u_{-} c f d}$ is the inflation shock for services other than housing and utility services.

Equations (3)-(5) are standard Phillips curves. These equations rely on the fundamental idea that monetary policy main goal is to provide a nominal anchor for inflation. Other goals, such as targeting the output gap, should be aligned with it. The equations show that in equilibrium actual inflation will correspond to its expected level (the weighted average of the future and past values) if total output corresponds to its potential level. The equations are based on the premise that when firms change prices, they consider the expected inflation and marginal costs. In this case, the output gap approximates real marginal costs dynamics. Therefore, the central bank targets inflation by affecting the output gap.

It is important to note that expectations are a weighted average of future and past inflation values. If inertia is low (the coefficient $\beta_{1}$ is near 1 ), a small sustained change in the interest rate will lead to a significant and immediate change in current inflation, which may also be interpreted as confidence in the current monetary policy. On the contrary, with high inertia, only accumulated changes in interest rates can move inflation in the right direction. It is assumed that the higher is the inertia of expectations, the lower is the output gap coefficient $\beta_{3}$, since the expectations of future price changes are also affected by demand.

The size of coefficient $\beta_{2}$ indicates the impact of the exchange rate on inflation. The more goods are imported, the higher the value of this coefficient is (for nonfood products -0.4 ; for food products -0.3 ; for services -0.2 ).

Relative price is the ratio of the price growth rate for a given component (food products, non-food products, or services) to the price growth rate for the whole region. The relative price gap is the deviation of this ratio from the equilibrium value. It is assumed that in a state of equilibrium food inflation corresponds to general regional inflation, and the dynamics of non-food inflation and service inflation, among other things, can be described by the Balassa-Samuelson effect. The logic of this effect is as follows. Regions create tradable goods (for simplicity, we will assume them to be non-food products) and non-tradable goods (services). The price for tradable goods is determined by the law of one price (i.e., the prices for these products are approximately the same across regions). When a region experiences a positive productivity shock in a tradable sector, wages in that sector of that region rise. Given the mobility in the labour market, wages in the non-tradable sector will also increase. Since the growth of prices in the tradable sector is limited by the law of one price, upward pressure will be exerted only on the prices of goods in the non-tradable sector of that region, which results in an increase of the overall price level in that region. Therefore, the effect explains the price differences in different regions with different costs of non-tradable goods. Coefficient for the given variable $\beta_{4}$ is designed in such a way as to take into account the impact of the historical dynamics of relative prices on inflation components. 


\section{Inflation equation for housing and utility services}

$$
\pi_{t}^{u_{-} c f d}=\beta_{1}^{u_{-} c f d} \times \pi_{t}^{\text {target }}+\left(1-\beta_{1}^{u_{-} c f d}\right) \times \pi_{t-1}^{u_{-} c f d}+\varepsilon_{t}^{u_{-} c f d},
$$

where $\pi_{t}^{u_{c} c f d}$ is the inflation for housing and utility services, $\pi_{t}^{\text {target }}$ is the inflation target, and $\varepsilon_{t}^{u \_c f d}$ is the shock of housing and utility services.

Inflation equation (6) for housing and utility services is modelled separately, and, since this component is regulated, its dynamics corresponds to the inflation target ${ }^{5}$ adjusted for previous indexation.

In the rest of Russia, inflation is formed separately. As in the case of the output gap, the dynamics of inflation for Russia as a whole is a weighted average of regional price growth rates:

$$
\pi_{t}^{r u}=c p i_{-} c f d_{-} w e i g h t \times \pi_{t}^{c f d}+\left(1-c p i_{-} c f d_{-} w e i g h t\right) \times \pi_{t}^{r o r},
$$

where $c p i \_c f d_{-} w e i g h t$ is the weight of inflation in the CFD in Russia's inflation.

\section{UIP equation}

The exchange rate and interest rates are interrelated by UIP. This is an arbitrage condition, which indicates that the expected change in the exchange rate (the difference between the expected and actual values) must be offset by the interest rate differential (the difference between the Russian and foreign rates) adjusted for the country risk premium.

$$
e_{s_{t}}^{r u b / u s d}-s_{t}^{r u b / u s d}=\left(i_{t}^{r u}-i_{t}^{u s}-\operatorname{prem}_{t}^{r u}\right) / 4+\varepsilon_{t}^{s^{r u b / u s d}},
$$

where $e_{s_{t}}^{r u b / u s d}$ is the expected exchange rate, $s_{t}^{r u b / u s d}$ is the exchange rate, $i_{t}^{r u}$ is the interest rate in Russia, $i_{t}^{u s}$ is the foreign interest rate, prem $_{t}^{r u}$ is the country risk premium, and $\varepsilon_{t}^{s^{r u b} / u s d}$ is the exchange rate shock.

The exchange rate expectations assume to combine both the back-looking $\left(s_{t-1}^{\text {rub/usd }}\right)$ and forward-looking $\left(E s_{t+1}^{\text {rub/usd }}\right)$ components:

$$
\begin{aligned}
e_{s_{t}}^{\text {rub/usd }} & =\tau_{1} \times E s_{t+1}^{\text {rub } / \text { usd }} \\
& +\left(1-\tau_{1}\right) \times\left(s_{t-1}^{\text {rub } / \text { usd }}+2 \times\left(\pi_{t}^{\text {target }}+\Delta \overline{z_{t}}-\pi_{s s}^{u s}\right) / 4\right),
\end{aligned}
$$

where $e_{s_{t}}^{r u b / u s d}$ is the expected value of the exchange rate, $s_{t}^{r u b / u s d}$ is the exchange rate, $E s_{t+1}^{\text {rub }}$ usd is the forward-looking component of the exchange rate expectations, $\pi_{t}^{\text {target }}$ is the inflation target in Russia, $\pi_{s s}^{u s}$ is the long-term value of inflation abroad, and $\Delta \bar{z}_{t}$ is the equilibrium path of the real exchange rate.

This equation assumes that the change in the exchange rate is determined by fundamental factors, such as the inflationary differential (the difference between the long-term inflation in Russia and abroad) and the equilibrium path of the real exchange rate.

\footnotetext{
${ }^{5}$ See 'Strategy for the Development of Competition and Antimonopoly Regulation in the Russian Federation for the Period until 2030' at http://www.consultant.ru/document/cons_doc_LAW_334321/ [In Russian].
} 
The equation also describes the exchange rate channel. If the central bank increases the interest rate while foreign rates do not change, the home currency appreciates. A higher domestic interest rate attracts short-term capital, which, all other things being equal, puts strengthening pressure on the exchange rate. A stronger exchange rate puts downward pressure on the prices of tradable goods and, accordingly, on inflation in general. Therefore, there is a link between the domestic interest rate and inflation through the exchange rate channel.

Monetary policy rule

$$
\begin{aligned}
i_{t}^{r u}=\delta_{1} \times i_{t-1}^{r u}+\left(1-\delta_{1}\right) \times\left(\overline{r_{t}^{r u}}+E \pi_{t+4}^{4, r u}\right. \\
\left.+\delta_{2} \times\left(E \pi_{t+4}^{4, r u}-E \pi_{t+4}^{\text {target }}\right)\right)+\varepsilon_{t}^{i},
\end{aligned}
$$

where $i_{t}^{r u}$ is the nominal interest rate, $\bar{r}_{t}^{r u}$ is the real equilibrium interest rate, $\pi_{t}^{4, r u}$ is the inflation rate (year-on-year), $\pi_{t}^{\text {target }}$ is the inflation target, and $\varepsilon_{t}^{i}$ is the monetary policy shock. The sum of real equilibrium interest rate and expected inflation represent a neutral rate.

It is assumed that the monetary policy instrument is based on the short-term nominal interest rate. The central bank sets it in such a way as to achieve the inflation target $\pi_{t}^{\text {target }}$. The standard equation for the rule used by the central bank to set the rate also includes the output gap, but, in our version, there is no such assumption, which underscores the fact that the main goal of the Bank of Russia is to minimise the deviation of the expected inflation from the target. The interest rate deviates from its neutral level so as to reach the target.

At this time, the main purpose of the model is to forecast regional economic indicators. It should be noted, that in the future for structural analysis purposes it is necessary to improve and refine the model both in terms of estimation of the parameters and in terms of adding more equations. First, calibration was selected as the main method for determining the coefficients (calibrated parameter values are given in Table 1). The main argument for criticising this decision is that there is no clear criteria for selecting parameters for the calibration. In addition, the expert judgments underpinning the parameterisation may be inconsistent. In current practice, it is customary to use a combination of calibration and econometric estimations and to conduct additional research. Second, QPMs are usually the result of solving equations which are based on microeconomic foundations and consider consumers maximising expected utility and firms operating amid monopolistic competition. However, the QPM itself is not based on the microeconomic foundations entirely; in addition to rational expectations, it also takes into account substantial inertia, which greatly simplifies the model compared to DSGE. Third, as in a standard QPM, many trends in this model are modelled by autoregressions. On the one hand, this makes the model apparatus simple and convenient to use for forecasting purposes. On the other hand, this simplification does not allow the model to take into account the fundamental economic factors affecting the expected trajectories of variables. In this regard, the 
model cannot forecast crises and analyse structural transformations of the economy in the long term. This model can be further improved by including additional equations or variables, depending on the objectives of the structural analysis.

Table 1. Calibrated parameters of key behavioural equations

\begin{tabular}{|c|c|c|}
\hline Parameters & Description & Value \\
\hline$\alpha_{1}^{c f d}$ & Coefficient for the expectations in the output gap equation & 0.4 \\
\hline$\alpha_{2}^{c f d}$ & Coefficient for the backward-looking lag in the output gap equation & 0.3 \\
\hline$\alpha_{3}^{c f d}$ & Coefficient for the market rate gap in the output gap equation & 0.1 \\
\hline$\alpha_{4}^{c f d}$ & Coefficient for the real effective exchange rate gap in the output gap equation & 0.05 \\
\hline$\alpha_{5}^{c f d}$ & Coefficient for the real oil price gap in the output gap equation & 0.02 \\
\hline$\alpha_{6}^{c f d}$ & Coefficient for effective external demand gap in the output gap equation & 0.05 \\
\hline$\alpha_{7}^{c f d}$ & Coefficient for the output gap of the rest of Russia in the output gap equation & 0.25 \\
\hline$\alpha_{8}^{c f d}$ & Coefficient for the budget deficit gap in the output gap equation & 0.15 \\
\hline$\beta_{1}^{p} p_{-} c f d$ & Coefficient for the expected food inflation in the Phillips curve for food products & 0.5 \\
\hline$\beta_{2}^{p} p_{-} c f d$ & Coefficient for the real exchange rate gap in the Phillips curve for food products & 0.3 \\
\hline$\beta_{3}^{p_{-} c f d}$ & Coefficient for the CFD output gap in the Phillips curve for food products & 0.3 \\
\hline$\beta_{4}^{p_{-} c f d}$ & Coefficient for the relative price gap in the Phillips curve for food products & 0.25 \\
\hline$\beta_{1}^{n p_{-} c f d}$ & Coefficient for the expected non-food inflation in the Phillips curve for non-food products & 0.5 \\
\hline$\beta_{2}^{n p_{-} c f d}$ & Coefficient for the real exchange rate gap in the Phillips curve for non-food products & 0.4 \\
\hline$\beta_{3}^{n p_{-} c f d}$ & Coefficient for the CFD output gap in the Phillips curve for non-food products & 0.3 \\
\hline$\beta_{4}^{n p_{-} c f d}$ & Coefficient for the relative price gap in the Phillips curve for non-food products & 0.25 \\
\hline$\beta_{1}^{\text {swup_cfd }}$ & $\begin{array}{l}\text { Coefficient for the expected inflation in the Phillips curve for services other than housing } \\
\text { and utility services }\end{array}$ & 0.5 \\
\hline$\beta_{2}^{\text {swup_cfd }}$ & $\begin{array}{l}\text { Coefficient for the real exchange rate gap in the Phillips curve for services other than } \\
\text { housing and utility services }\end{array}$ & 0.2 \\
\hline$\beta_{3}^{\text {swup_cfd }}$ & $\begin{array}{l}\text { Coefficient for the output gap in the Phillips curve for services other than housing and } \\
\text { utility services }\end{array}$ & 0.3 \\
\hline$\beta_{4}^{\text {Swup_cfd }}$ & $\begin{array}{l}\text { Coefficient for the relative price gap in the Phillips curve for services other than housing } \\
\text { and utility services }\end{array}$ & 0.25 \\
\hline$\beta_{1}^{u} c f f$ & Coefficient for the inflation target in the inflation equation for housing and utility services & 0.1 \\
\hline$\tau_{1}$ & Coefficient for the expected change of the exchange rate in the UIP & 0.55 \\
\hline$\delta_{1}$ & Coefficient for the interest rate lag in the monetary policy rule & 0.68 \\
\hline$\delta_{2}$ & Coefficient for the expected inflation deviation from the target in the monetary policy rule & 1.55 \\
\hline
\end{tabular}

\section{Model and forecasts properties}

To illustrate the model properties, let's consider the following two scenarios (and the corresponding impulse responses) - a positive one standard deviation demand shock in the CFD (Figure 1) and a positive one standard deviation shock in one of the inflation components in the CFD (Figure 2). These scenarios are selected because they reflect the regional specifics of the model. Scenarios with unexpected changes in other variables generally are standard for semi-structural models.

Scenario 1: A positive demand shock in the CFD. In the short term, the total demand in the CFD exceeds its equilibrium value, which makes output gap positive. 
The positive output gap puts upward pressure on all components of inflation in the CFD. Moreover, the components respond differently (due to Balassa-Samuelson effect, exchange rate pass-through effect). The higher growth rate of prices in the CFD accelerates inflation in Russia as a whole, which, in turn, triggers a monetary policy response (an increase in the nominal interest rate). The actions taken by the monetary authorities make it possible to balance the system. At the same time, it should be noted that the output gap in the rest of Russia is also increasing, as it is affected by the demand from the CFD. However, this model does not consider the spillover effects of inflation between the regions, and, as a result, the inflation in the rest of Russia does not increase to follow the inflation in the CFD, and we assume that inflation in the rest of Russia declines in response to the interest rate hike.

Figure 1. Impulse responses of variables to demand shock in the CFD
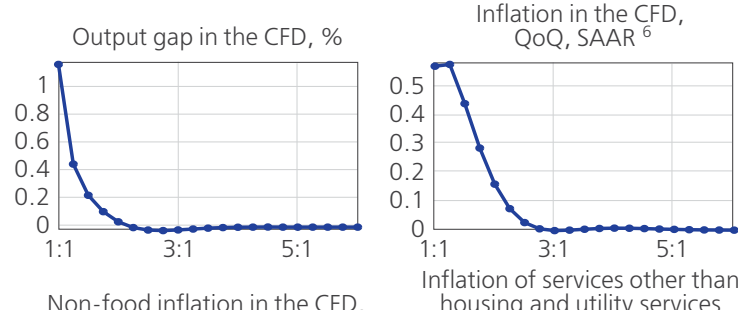

Non-food inflation in the CFD, QOQ, SAAR in the CFD, QOQ, SAAR
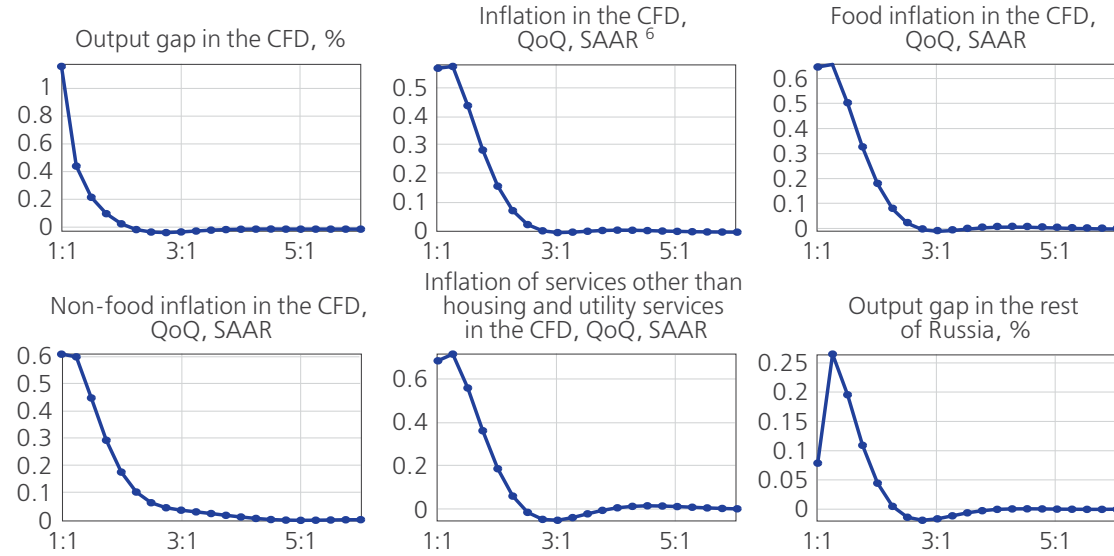

Inflation in the rest of Russia, QOQ, SAAR
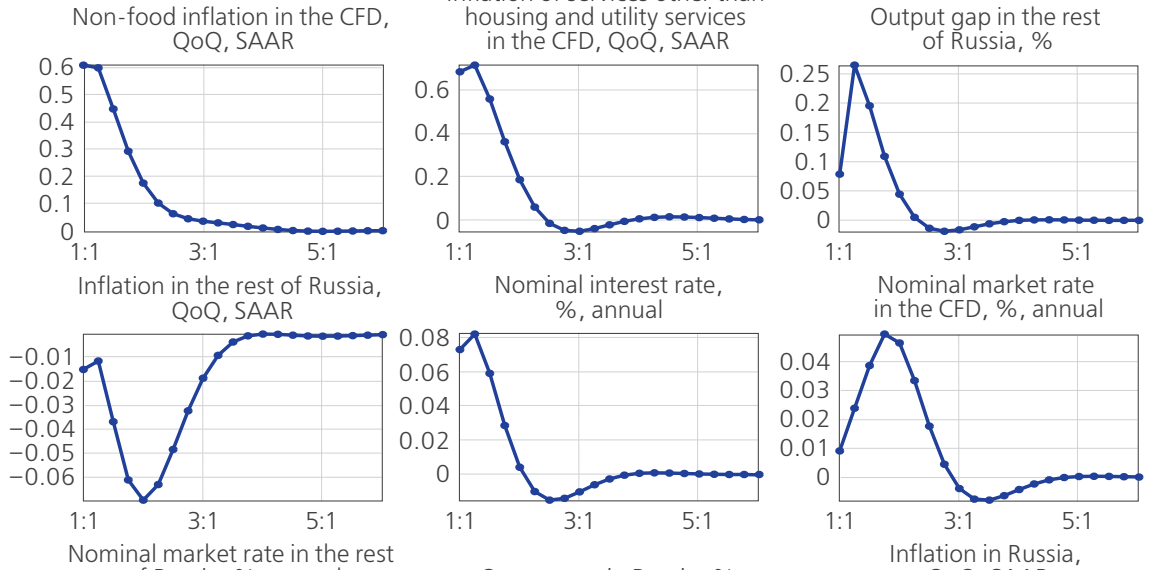

Nominal market rate in the CFD, \%, annual

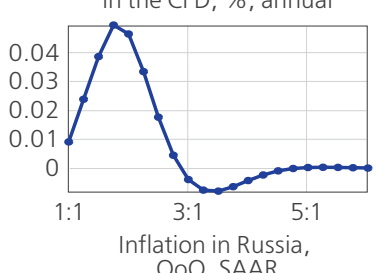

Output gap in Russia, \%
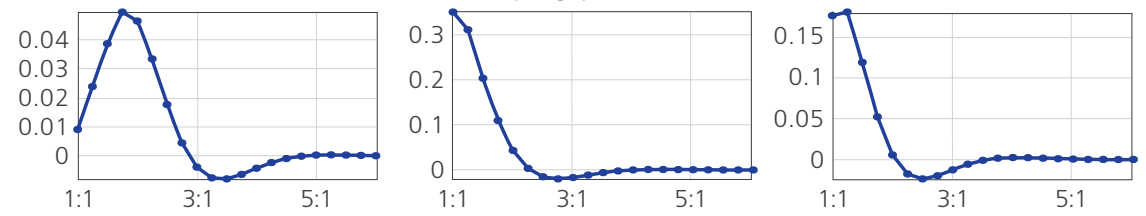

Source: author's calculations

Scenario 2: A positive shock of non-food inflation in the CFD. The higher growth rate of prices accelerates inflation both in the CFD and in Russia as a whole,

\footnotetext{
${ }^{6}$ Seasonally Adjusted Annualised Rate.
} 
which, in turn, triggers a monetary policy response (an increase in the nominal interest rate). The higher interest rate leads to the contraction of aggregate demand. As a result, output gap goes negative and puts downward pressure on inflation rates. Thus, the system returns to a steady state. At the same time, the output gap in the rest of Russia also decreases, as it is influenced by the demand from the CFD. However, this model does not consider the spillover effects, and, as a result, the inflation in the rest of Russia does not increase to follow the inflation in the CFD, and it is assumed that inflation in the rest of Russia declines in response to the interest rate hike. Scenarios with shocks of other inflation components are similar.

Figure 2. Impulse responses of variables to the shock of non-food inflation in the CFD

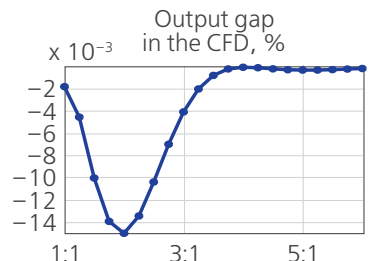

Non-food inflation in the CFD, QOQ, SAAR

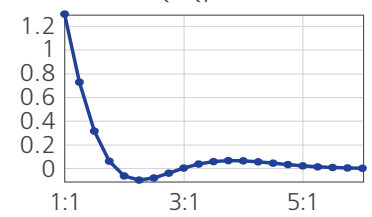

Inflation in the rest of Russia, QOQ, SAAR
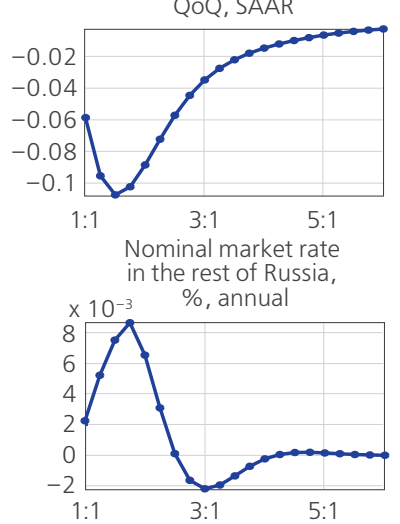

Inflation in the CFD, QOQ, SAAR

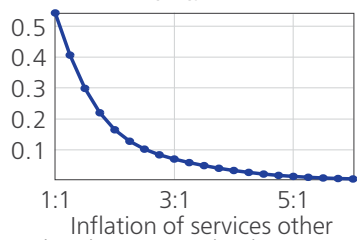

than housing and utility services in the CFD, QoQ, SAAR

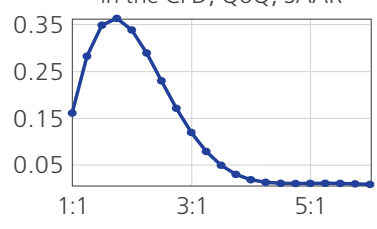

Nominal interest rate,

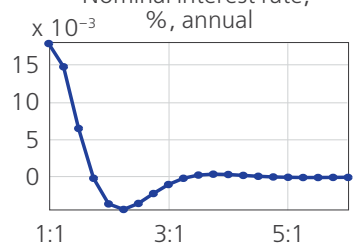

Output gap in the rest

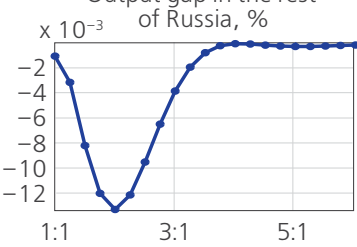

Food inflation in the CFD,

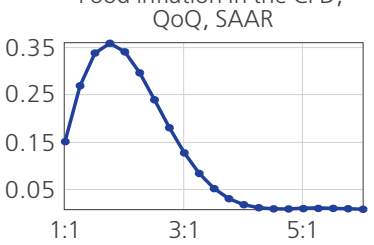

Output gap in the rest

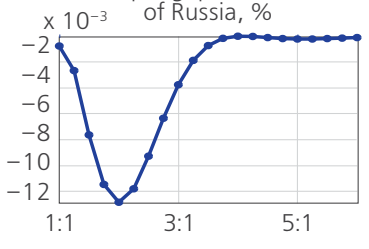

Nominal market rate in the

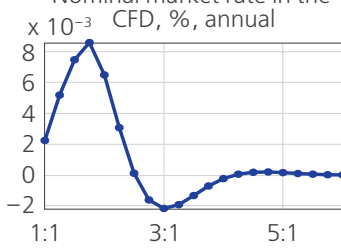

Inflation in Russia, QoQ, SAAR

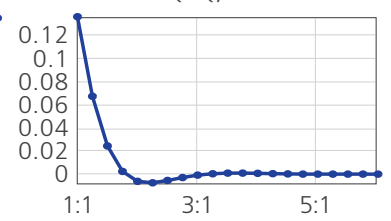

Source: author's calculations

The quality of the model is assessed using in-sample forecasts and by calculating NRMSE (Normalised Root-Mean-Square Error) of the forecast. In-sample forecasts within the sample are used to estimate how well calibrated a model is and how good it can predict the historical data if it had been used in the past 
(see Figure 3). Table 2 shows the NRMSEs of the forecast. It should be noted that NRMSEs are calculated for forecasts on the horizon from 2016 to 2019. This evaluation period is chosen because the model parameters are selected for the current economic conditions associated with the implementation of the inflation targeting policy. In earlier years, there were other monetary policy regimes (in 2004-2008, managing the trend and short-term exchange rate fluctuations; in 2009-2014, managing short-term exchange rate fluctuations and interest rates); accordingly, it was necessary to set other parameters for the model. Year 2015 was excluded, as it is a transition year with significant inflationary shocks due to sharp rouble depreciation after oil price decline, and the effects of the transition to a free-floating exchange rate.

The calculations of the in-sample inflation forecast do not include a revision of coefficients tested on historical data, since the model quality assessment involves only the current coefficients. In addition, they do not consider the expert adjustments made in retrospect. Tables $2-3$ shows that the NMRSEs are small, and, overall, the model handles the forecast on average two times better than a random walk model.

Figure 3. Forecast of inflation in the CFD within the sample, $\%$, YoY

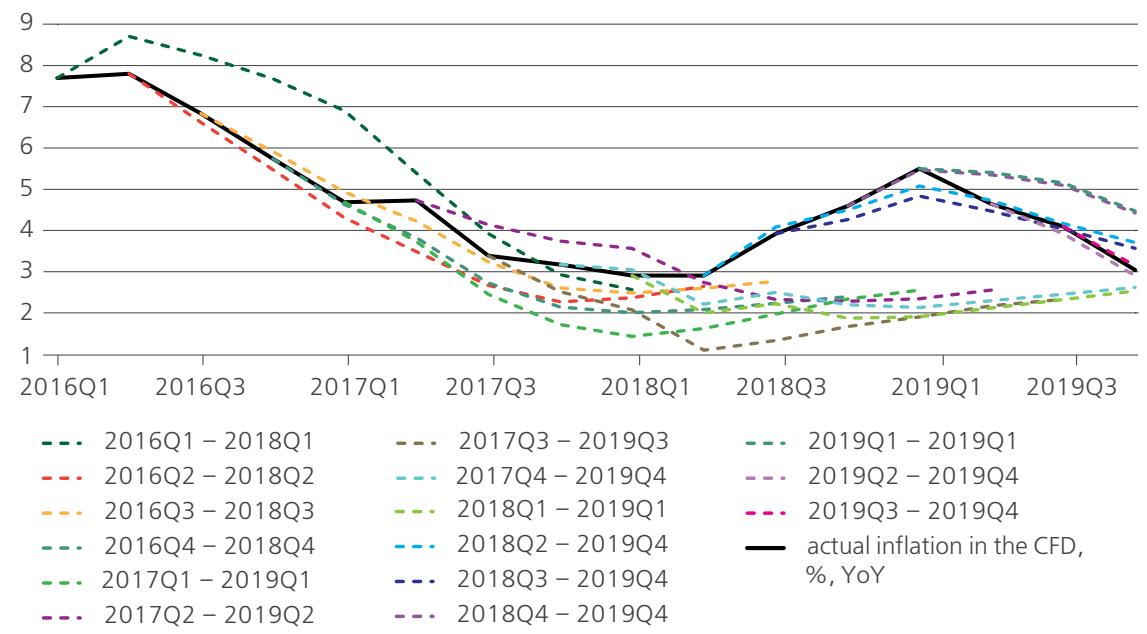

Source: author's calculations

Table 2. NRMSE of the forecast for the QPM, for the forecast period of 2016-2019

\begin{tabular}{lllllllll} 
& Q1 & Q2 & Q3 & Q4 & Q5 & Q6 & Q7 & Q8 \\
\hline NRMSE & 0.11 & 0.16 & 0.22 & 0.30 & 0.32 & 0.35 & 0.34 & 0.31 \\
\hline
\end{tabular}

Source: author's calculations

Table 3. The ratio of the NRMSE of the forecast for QPM and for the random walk model, for the forecast period of 2016-2019

\begin{tabular}{lllllllll} 
& Q1 & Q2 & Q3 & Q4 & Q5 & Q6 & Q7 & Q8 \\
\hline Ratio, \% & 39 & 45 & 50 & 59 & 58 & 62 & 56 & 53 \\
\hline
\end{tabular}

Source: author's calculations 


\section{Modelling results}

The model allows obtaining information on unobservable variables using the Kalman filter. The Kalman filter smoothes over the fluctuations in the historical period that are not related to fundamental factors and identifies the equilibrium levels of indicators. We assume that in the long term the equilibrium values converge to the stationary state levels. Therefore, filtering makes it possible to estimate the size of the gaps for the variables used in the model. Below is the filter's estimates of output, output gap, and inflation in the CFD and the rest of Russia, as well as the exchange rate and neutral interest rate, which are the starting point for making expert judgments at further stages.

Up until 2008, the CFD economy, as well as the Russian economy as a whole, experienced rapid growth associated with recovery after the beginning of the 2000s, which was reflected in a higher-than-potential GRP growth and, accordingly, a positive output gap. Then, the period of rapid economic growth was interrupted by the global financial and economic crisis, which hit all Russian regions substantially. During the crisis the rouble depreciated by more than $30 \%$ in nominal terms, and the collapse of external demand provoked a significant drop in output in all Russian regions, including the CFD. A long period of economic recovery began after the crisis. Recovery was slow due to a decline in investment activity and the slower growth of real consumption.

In 2013-2014, the potential growth of the economy slowed down due to structural problems exacerbated further by a downturn in oil prices. Despite this, the inflation began to accelerate and in 2014 went beyond the target range set by the Bank of Russia. Inflation accelerated following the weakening of national currency and the import restrictions imposed in response to Western sanctions. By the end of 2014, the Bank of Russia had switched to an inflation-targeting regime and a floating exchange rate, and inflation began to stabilise in 2015. At the same time, inflation in the CFD exceeded the national level for a long time, which may be related to high average incomes and effective demand.

Starting from 2020Q2, the output gaps in the CFD and the rest of Russia were significantly negative, which is associated with the recession triggered by the pandemic. In addition, downward pressure was exerted by lower oil prices and a slowdown of business activity abroad. At the same time, it is estimated that the fall of the CFD GRP in 2020 was slightly less than in the rest of Russia, which may be associated with the growth of the industrial sector in the CFD (which fell in Russia as a whole). According to our estimates, the potential trajectories of GRP in the CFD and the rest of Russia have also declined, in particular, after the suspension of investment projects, restrictions on oil production under the OPEC+ deal, contraction of the small and medium enterprises sector. With the onset of the crisis, inflation accelerated due to increased panic buying and a weaker exchange rate before slowing down amid weak consumer demand, deterioration in the labour 
market, and decline of household incomes. The Bank of Russia responded by lowering interest rates to soften the monetary stance. In future, we expect nominal interest rates to move to a long-term neutral value, which we estimate at 5.5\%.

Figure 4. The CFD real GRP, $100 \times$ log
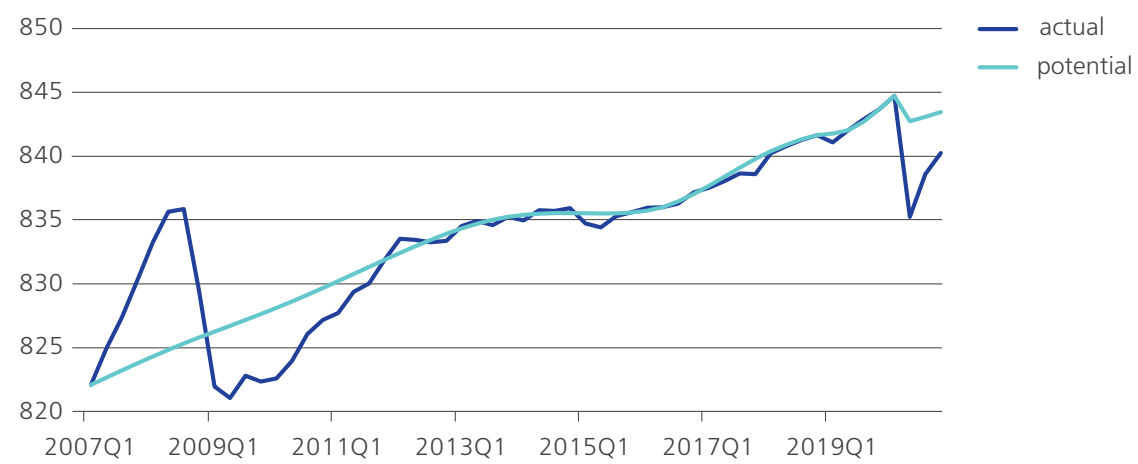

Source: Rosstat, author's calculations

Figure 5. The CFD output gap, $\%$

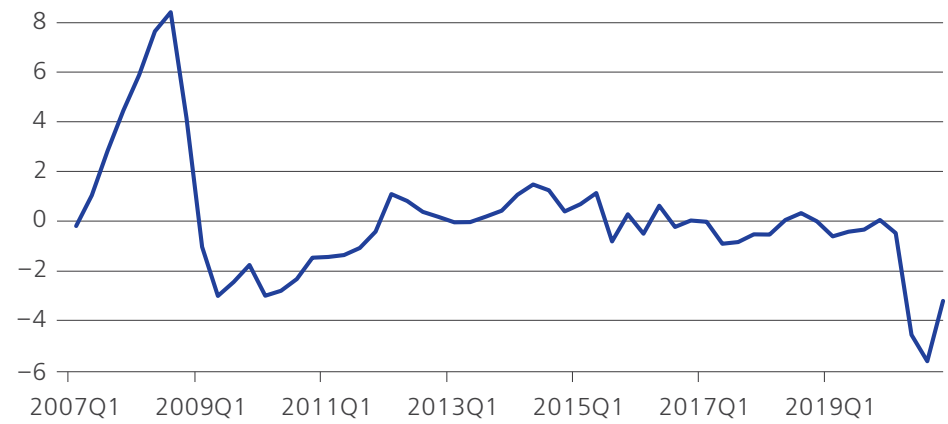

Source: author's calculations

Figure 6. The CFD inflation, QoQ, SAAR

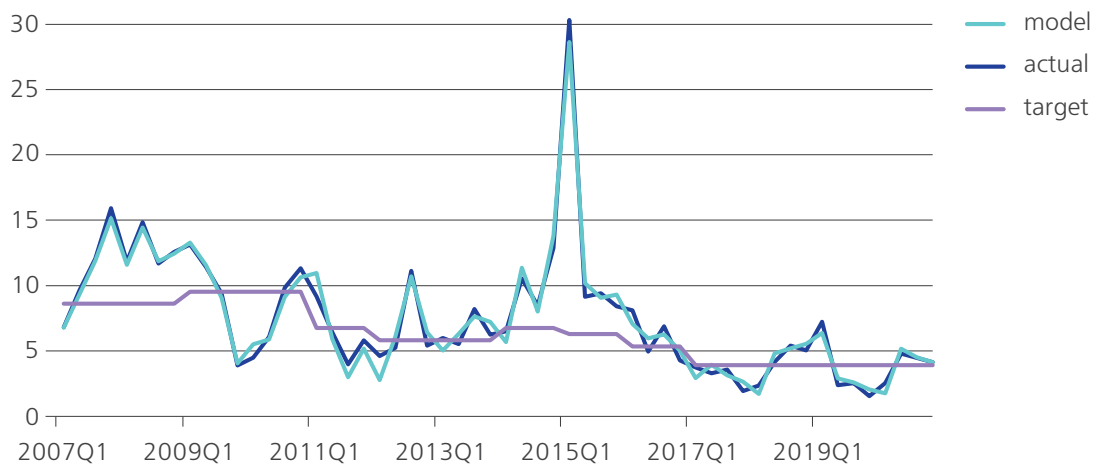

Source: Rosstat, author's calculations 
Figure 7. Real GRP of the rest of Russia, $100 \times$ log

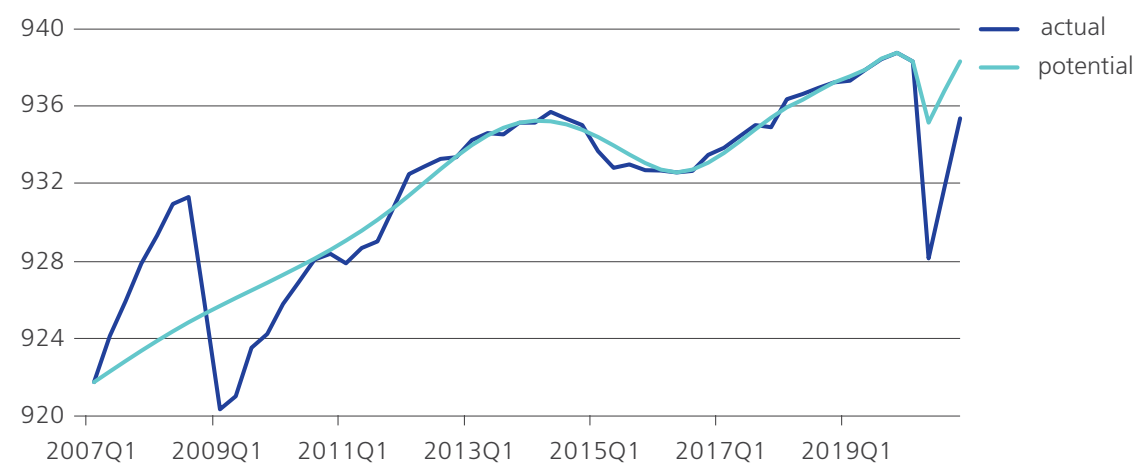

Source: author's calculations

Figure 8. Output gap in the rest of Russia, $\%$

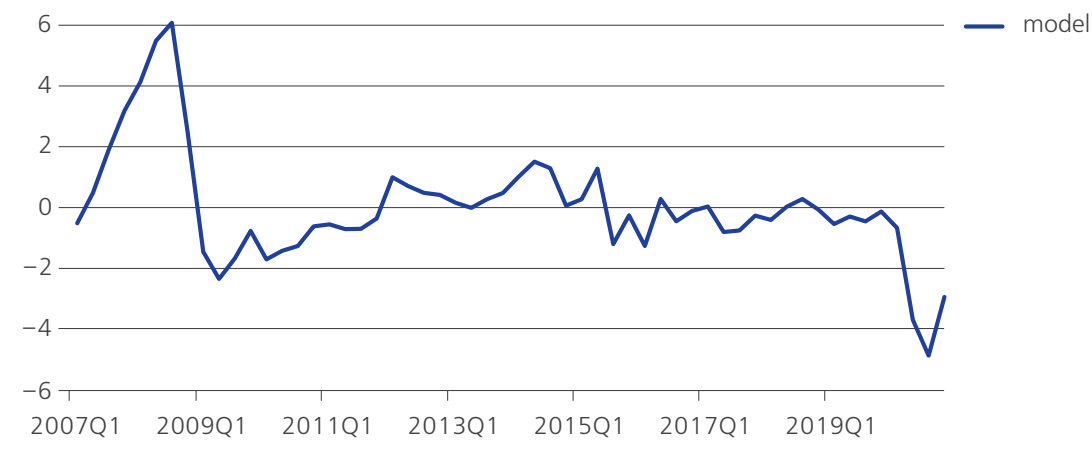

Source: author's calculations

Figure 9. Inflation in the rest of Russia, QoQ, SAAR

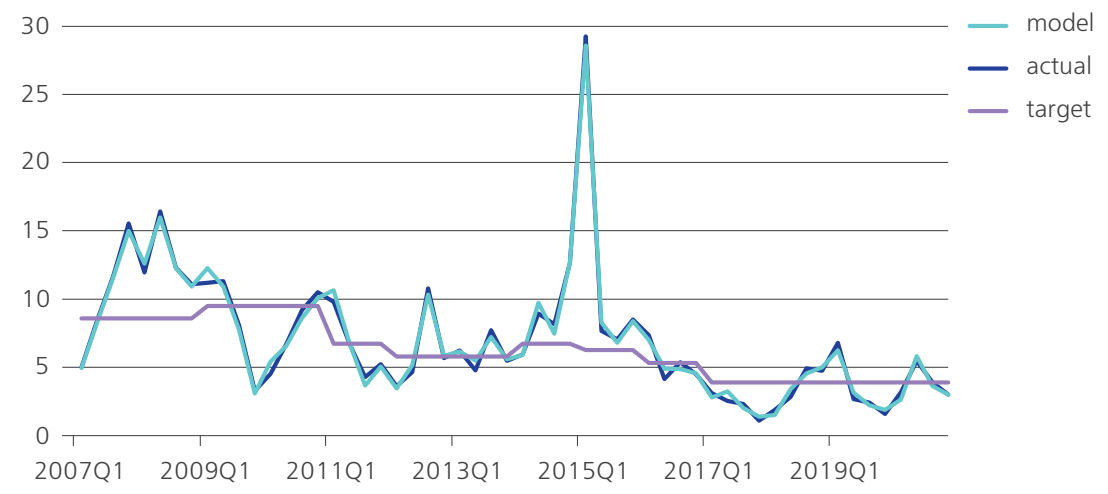

Source: Rosstat, author's calculations 
Figure 10. Real exchange rate, $100 \times \log$

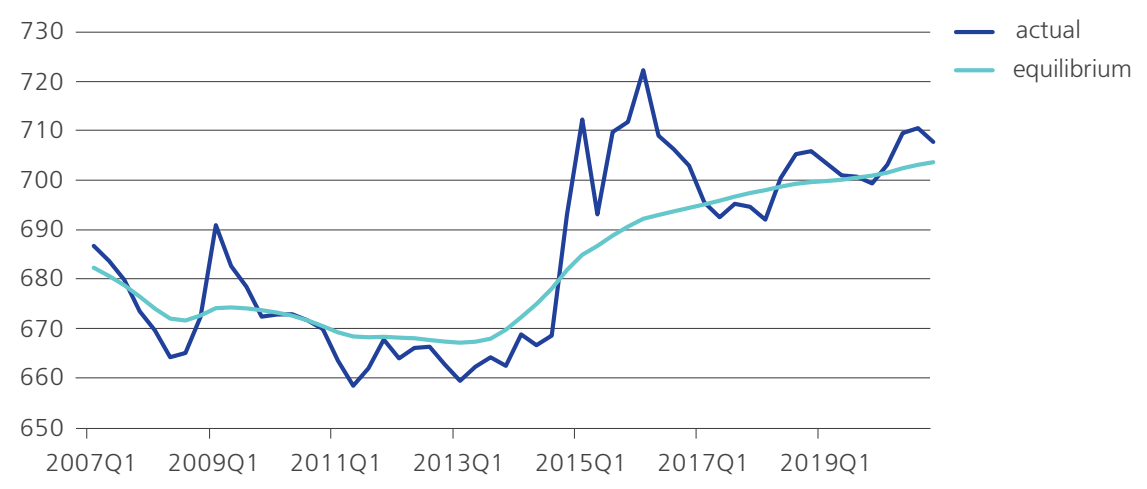

Source: Bank of Russia, author's calculations

Figure 11. Nominal neutral interest rate estimate, $\%$

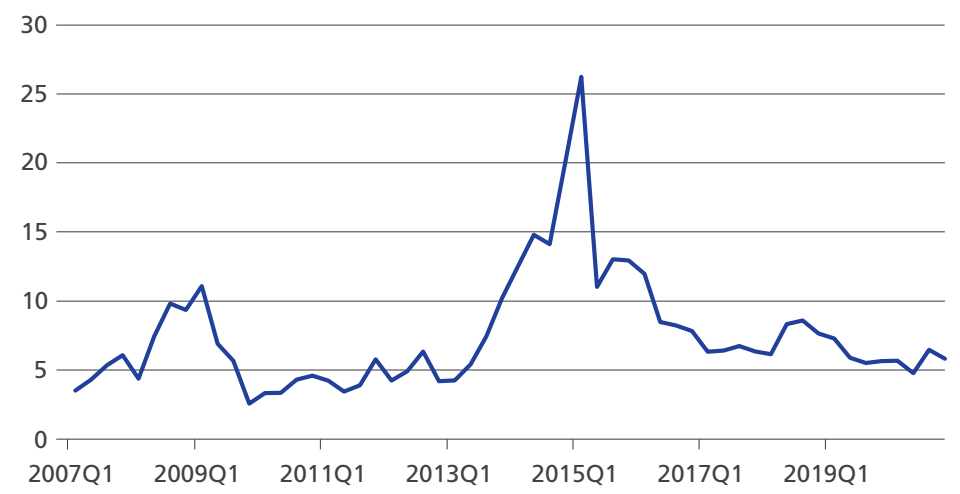

Source: author's calculations

To analyse the comparative importance of internal and external shocks for the region, we can consider the decomposition of key macroeconomic variables of the regions (inflation, output, output gap, market rate gap) into shocks. On the one hand, the CFD economy is affected, among other things, by shocks in other Russian regions (Figures 12-14). In 2016-2020, a key factor that contributed to the decomposition of inflation, and the gap in the market rate in the CFD was inflation in the rest of Russia. In addition, the CFD output gap and GRP are also affected by demand, inflation, and fiscal policies in other regions. On the other hand, other regions are also affected by unexpected changes in the CFD (Figures 15-18). For example, demand shocks in the CFD contribute to the output level and output gap in the regions, and food inflation shocks contribute to overall inflation in the rest of Russia. All this suggests that the regions are closely interrelated, and shocks in one region make a significant contribution to the dynamics of indicators in other regions. 
Figure 12. Decomposition of the CFD inflation by shocks, QoQ, SAAR

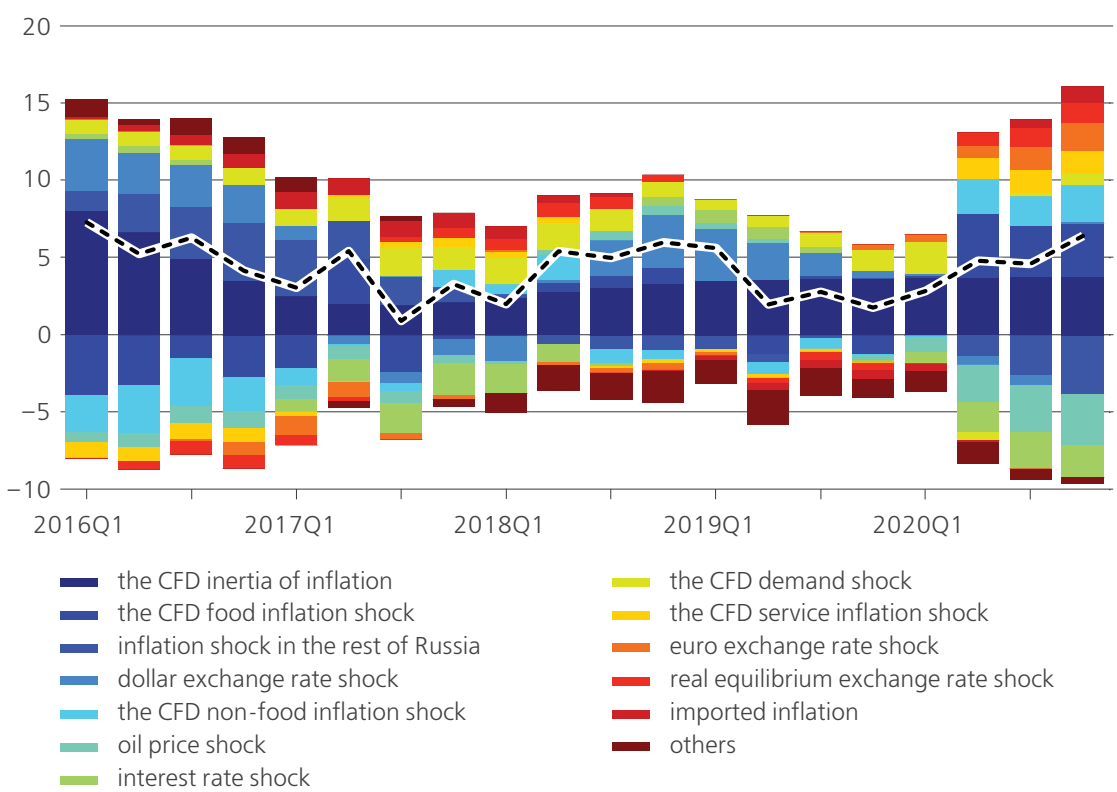

Source: author's calculations

Figure 13. Decomposition of the CFD output gap by shocks, $\%$

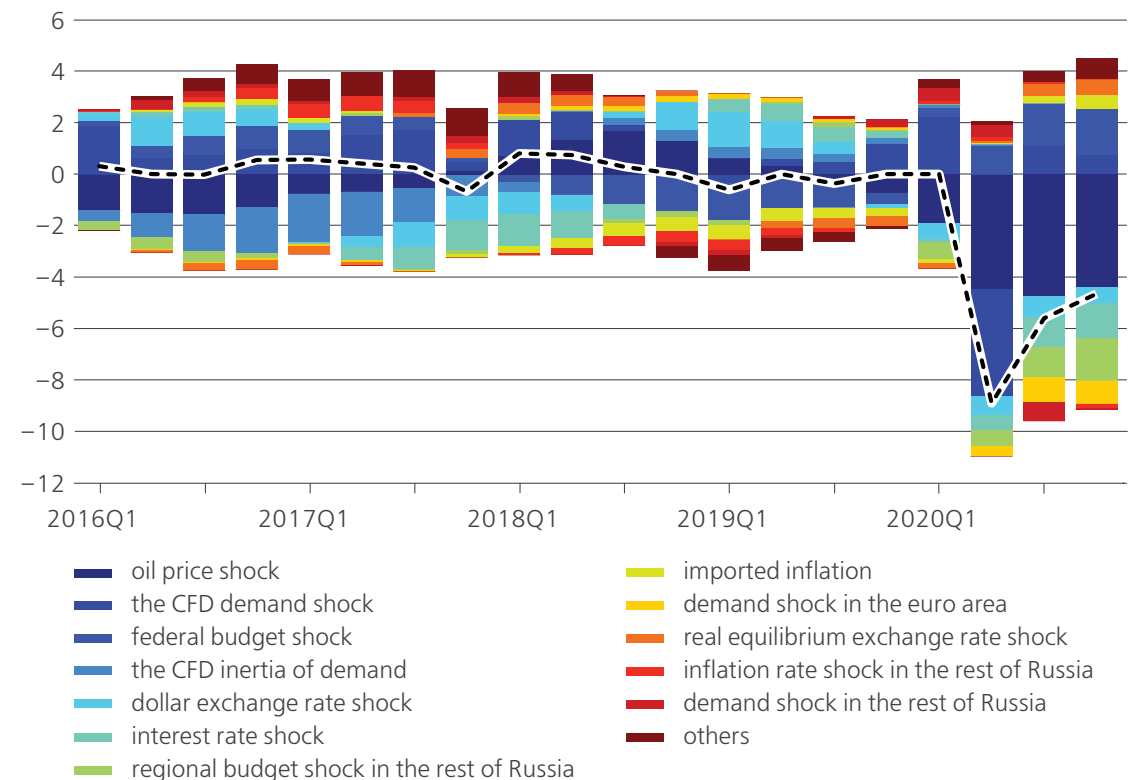

Source: author's calculations 
Figure 14. Decomposition of the CFD market rate gap by shocks, $\%$

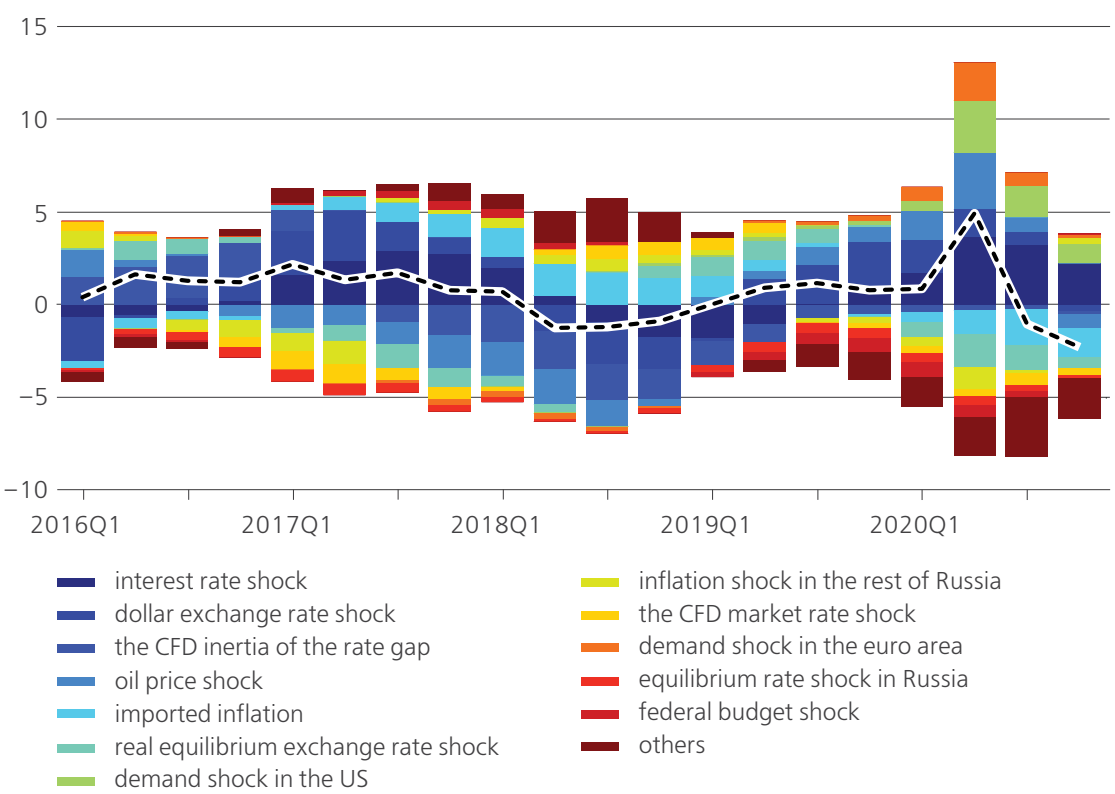

Source: author's calculations

Figure 15. Decomposition of inflation in the rest of Russia by shocks, QoQ, SAAR

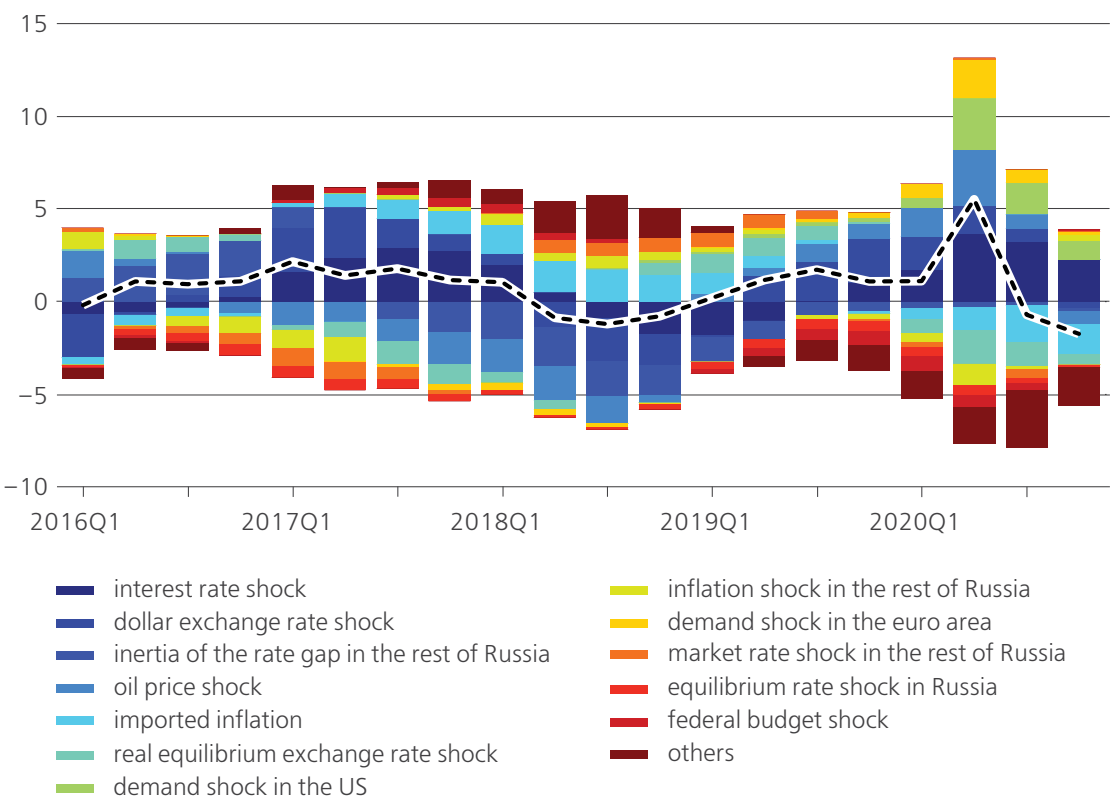

Source: author's calculations 
Figure 16. Decomposition of the output gap in the rest of Russia by shocks, $\%$

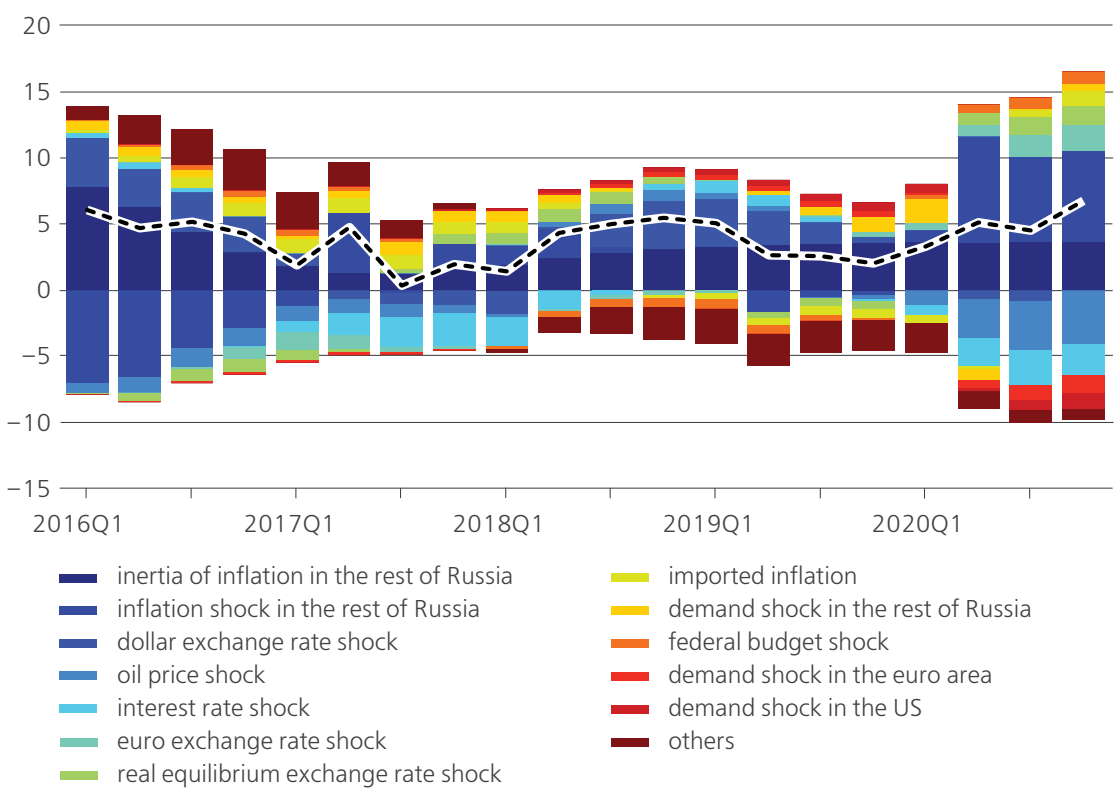

Source: author's calculations

Figure 17. Decomposition of the GRP in the rest of Russia by shocks, \%

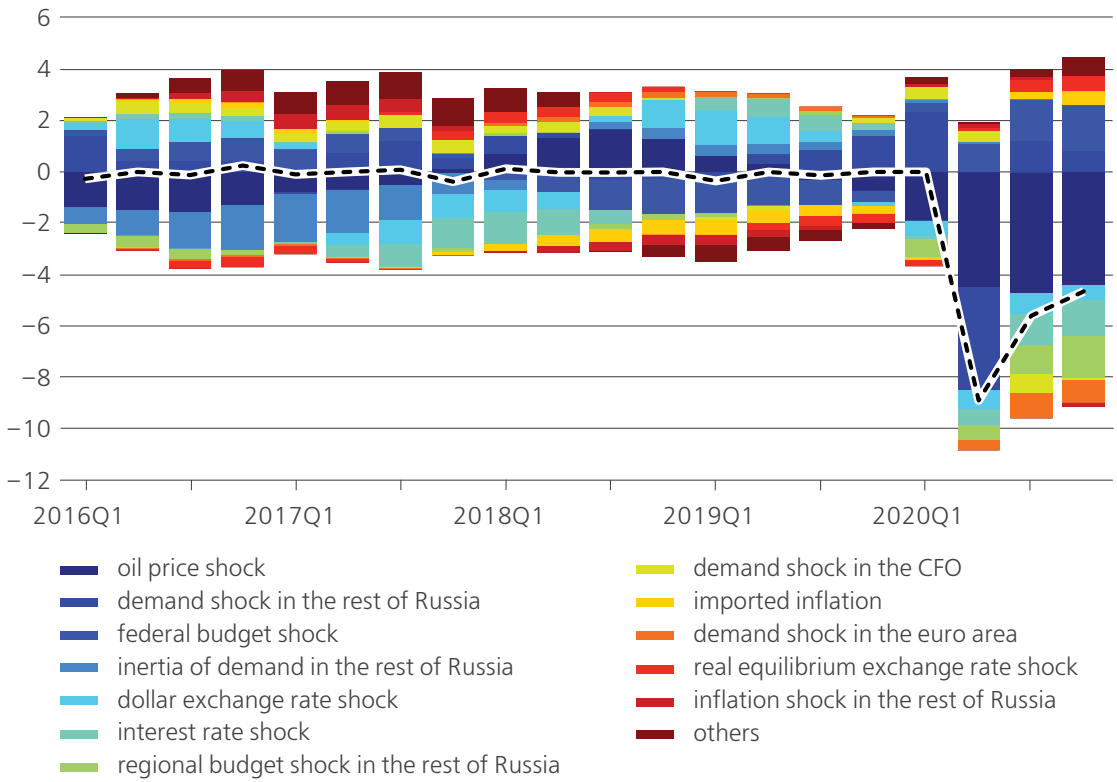

Source: author's calculations 
Figure 18. Decomposition of the market rate gap in the rest of Russia by shocks, $\%$

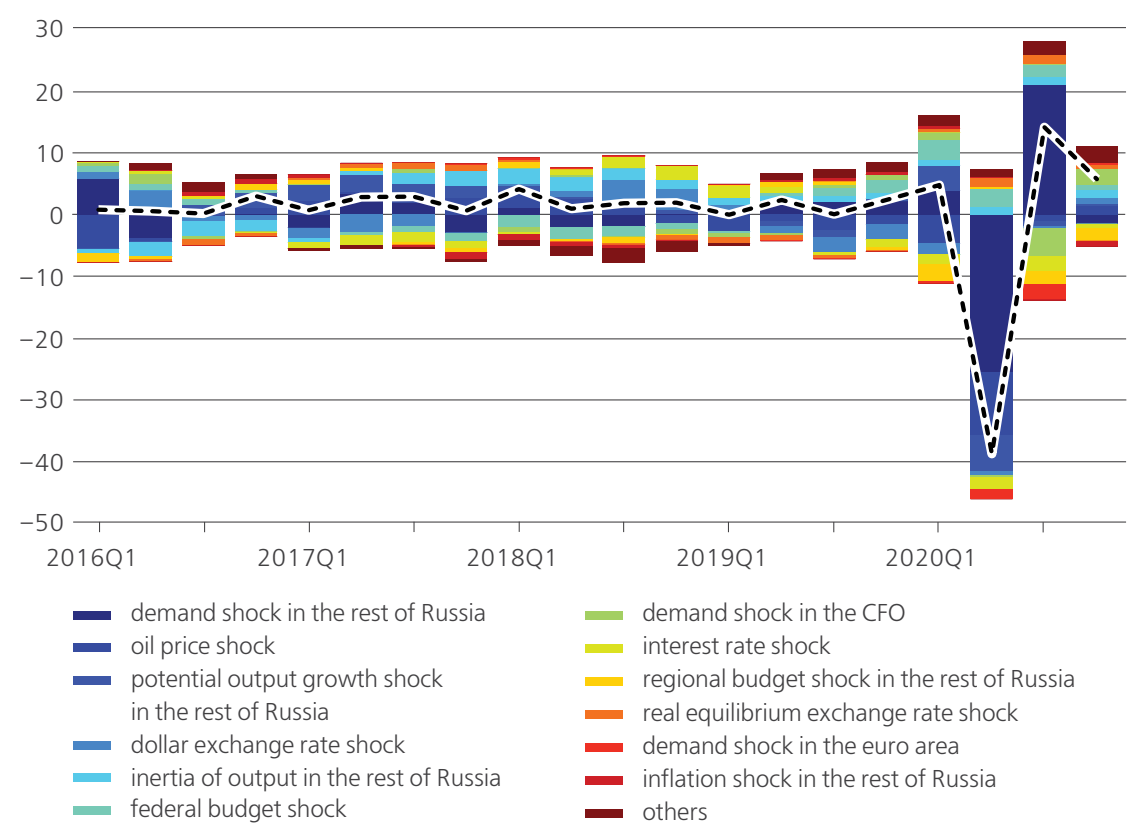

Source: author's calculations

\section{Conclusion}

At the end of 2014, the Bank of Russia switched to an inflation targeting regime. This increased the importance of forecasts for the expected trajectory of relevant indicators, in particular, inflation under various scenarios at the regional level. The Bank of Russia targets expected inflation in Russia as a whole, which is an aggregate indicator based on weighted average of rates of inflation in the regions. However, the Russian economy is fairly heterogeneous across the regions, which leads to the regional differentiation of inflation rates. To implement a monetary policy effectively, it is necessary to consider all information available at the time of decision-making and envision the future trajectories of indicators, including regional ones.

Currently, there is not much specialised literature covering contemporary approaches to modelling and forecasting the regional inflation rates within a common currency area. The paper presents a regional QPM, which is a tool for studying and predicting the regional characteristics within a country. It is a modification of a standard QPM which considers both the peculiarities of regional economies and their links to each other. In the model, Russia is divided into two regions - the CFD and the rest of Russia, which makes it possible to analyse the impact of local and nationwide shocks. 
The model not only enables one to make forecasts and improve the quality of discussion in the decision-making process but can also be used for research purposes. We are planning to use this tool in the future to study the stability in regional differentiation of inflation. In addition, the experience of using the CFD case to build a model can be scaled to other Russian regions.

\section{Appendix is available at http://rjmf.econs.online/en; doi.org/10.31477/rjmf.202102.50}

\section{References}

Albonico, A., Calès, L., Cardeni, R., Croitorov, O., Ferroni, F., Giovannini, M., Hohberger, S., Pataracchia, B., Pericoli, F., Raciborski, R., Ratto, M., Roeger, W. and Vogel, L. (2017). The Global Multi-Country Model (GM): An Estimated DSGE Model for the Euro Area Countries. JRC Working Papers in Economics and Finance, N 10. https://doi.org/10.2760/901714

Bank of Russia (2020). Monetary Policy Guidelines for 2021-2023.

Beck, G., Hubrich, K. and Marcellino, M. (2009). Regional Inflation Dynamics Within and Across Euro Area Countries and a Comparison with the United States. Economic Policy, 24(57), pp. 142-184. https://doi.org/10.1111/j.1468-0327.2009.00214.x

Beneš, J., Hlédik, T., Vávra, D. and Vlček, J. (2003). The Quarterly Projection Model and its Properties. In: W. Coats, D. Laxton and D. Rose, eds. The Czech National Bank's Forecasting and Policy Analysis System. Prague: Czech National Bank, pp. 63-98.

Berg, A., Karam, P. and Laxton, D. (2006a). A Practical Model-Based Approach to Monetary Policy Analysis - Overview. IMF Working Paper, N 80. https://doi.org/10.5089/9781451863406.001

Berg, A., Karam, P. and Laxton, D. (2006b). Practical Model-Based Monetary Policy Analysis A How-To Guide. IMF Working Paper, N 81. https://doi.org/10.5089/9781451863413.001

Borodin, A. D. (2014). Strukturnoye makroekonomicheskoye modelirovaniye dlya tseley tsentral'nogo banka [Structural Macroeconomic Modeling for the Purposes of the Central Bank]. Moscow: Higher School of Economics. [In Russian].

Borodin, A. D., Gorbova, E. A., Plotnikov, S. V. and Plushchevskaya, Y. L. (2008). Otsenka potentsial'nogo vypuska i drugikh nenablyudayemykh peremennykh $v$ ramkakh modeli transmissionnogo mekhanizma monetarnoy politiki (na primere Rossii) [Estimation of Potential Output and Other Unobservable Variables Within the Model of the Transmission Mechanism of Monetary Policy (on the Example of Russia)]. In: Problemy vybora effektivnoy denezhno-kreditnoy politiki v usloviyakh perekhodnoy ekonomiki: sbornik dokladov II Mezhdunarodnoy nauchno-prakticheskoy konferentsii, Minsk, 19-20 maya 2008. Minsk: National Bank of the Republic of Belarus, 2008, pp. 119-143. [In Russian].

Burriel, P., Fernández-Villaverde, J. and Rubio-Ramírez, J. F. (2010). MEDEA: A DSGE Model for the Spanish Economy. SERIEs - Journal of the Spanish Economic Association, 1(1-2), pp. 175-243. https://doi.org/10.1007/s13209-009-0011-x 
De Haan, J. (2010). Inflation Differentials in the Euro Area: A Survey. In: J. Haan, H. Berger, eds. The European Central Bank at Ten. Berlin, Heidelberg: Springer, pp. 11-32. https://doi.org/10.1007/978-3-642-14237-6_2

Demidenko, M., Karachun, O., Korshunov, D., Lipin, A. and Hrebicek, H. (2016). Forecasting System for the Eurasian Economic Union. Joint Report by the Eurasian Economic Commission and the Eurasian Development Bank. Moscow: EEC.

Deryugina, E., Karlova, N., Ponomarenko, A. and Tsvetkova A. (2019). The Role of Regional and Sectoral Factors in Russian Inflation Developments. Economic Change and Restructuring, 52(4), pp. 453-474. https://doi.org/10.1007/s10644-018-9232-y

Gadatsch, N., Hauzenberger, K. and Stähler N. (2016). Fiscal Policy During the Crisis: A Look on Germany and the Euro Area with GEAR. Economic Modelling, 52(B), pp. 997-1016. https://doi.org/10.1016/j.econmod.2015.10.038

Jakab, Z., Lukyantsau, P. and Wang, S. (2015). A Global Projection Model for Euro Area Large Economies. IMF Working Paper, N 50. https://doi.org/10.5089/9781498399609.001

Jeanfils, P. and Burggraeve, K. (2008). “NONAME”: A New Quarterly Model for Belgium. Economic Modelling, 25(1), pp. 118-127. https://doi.org/10.1016/j.econmod.2007.05.004

Mogilat, A. (2017). Obzor osnovnykh kanalov transmissionnogo mekhanizma denezhnokreditnoy politiki i instrumentov ikh analiza v Banke Rossii [Overview of Monetary Policy Transmission Mechanism Channels and Instruments of Their Analysis in the Bank of Russia]. Dengi i Kredit, 9, pp. 3-9. [In Russian].

Novak, A. and Shulgin, A. (2020). Denezhno-kreditnaya politika v ekonomike s regional'noy neodnorodnost'yu: podkhody na osnove agregirovannoy i regional'noy informatsii [Monetary Policy in an Economy with Regional Heterogeneity: Approaches Based on Aggregated and Regional Information]. Bank of Russia Economic Research Report Series. [In Russian]. https://www.cbr.ru/Content/Document/File/108035/wp_2003.pdf [accessed on 15 May 2021].

Orlov, A. (2021). Kvartal'naya prognoznaya model' Rossii [Quarterly Forecasting Model of Russia]. Moscow: Bank of Russia. [In Russian]. http://www.cbr.ru/Content/Document/ File/118791/inf_note_feb_2521.pdf [accessed on 15 May 2021].

Perevyshin, Y., Sinelnikov-Murylev, S. and Trunin, P. (2017). Determinants of Price Differentiation across Russian Regions. HSE Economic Journal, 21(3), pp. 361-384. [In Russian]. https://ej.hse.ru/2017-21-3/211109253.html [accessed on 15 May 2021].

Pienkowski, A. (2019). A Three-Country Macroeconomic Model for Portugal. IMF Working Paper, N 281. https://doi.org/10.5089/9781513519241.001

Sinelnikov-Murylev, S. G., Perevyshin, Y. N. and Trunin, P. V. (2020). Inflation Differences in the Russian Regions: an Empirical Analysis. Ekonomika regiona [Economy of Region], 16(2), pp. 479-493. [In Russian]. https://doi.org/10.17059/2020-2-11

Zhemkov, M. I. (2019). Regional Effects of Inflation Targeting in Russia: Factors of Heterogeneity and Structural Inflation Rates. Voprosy Ekonomiki, 9, pp. 70-89. [In Russian]. https://doi.org/10.32609/0042-8736-2019-9-70-89 